\title{
Translation as a Social Activity: Towards a Bourdieusian Understanding of Pickthall's Translation of the Quran
}

https://doi.org/10.33806/ijaes2000.21.2.4

\author{
Dana Muwafi and Shehdeh Fareh \\ University of Sharjah, UAE
}

\begin{abstract}
This paper argued for a fresh understanding of Pickthall's The Meaning of the Glorious Koran: An Explanatory Translation (1930) in light of Bourdieu's sociological work. The main objective of this study was to examine Pickthall's translation of the meaning of the Holy Quran utilizing Pierre Bourdieu's sociological model that employs the key concepts of field, capital and doxa. By hypothesizing a field which could be called 'the field of English translations of the meaning of the Holy Quran', the researchers aspired to understand the dynamics of this field and its structure through delineating the socio-cultural and socio-political forces. After conducting an analysis at the macro level, the researchers analyzed the paratextual elements of the translation, the data of which represent the starting point for Bourdieusian insights into the production of Pickthall's translation. The findings of the study revealed that Pickthall efficiently utilized paratextual material to accrue cultural, social, economic, and symbolic capital and defend his doxa thus enhancing his position in the field of English translations of the Holy Quran. The study concluded that Pickthall's is a social activity, situated in a social space, and carried out by translating agents, both individuals and organizations, who are in a ceaseless struggle over accumulating capital at stake in the field.
\end{abstract}

Keywords: Bourdieu, capital, paratexts, Pickthall, Quran, sociology

\section{Introduction}

The era of text is 'the' thing is over. Translators are no longer viewed as 'transcoders' or linguistic 'machines'. During the last two decades, Translation Studies has witnessed a paradigm shift of focus towards sociologically informed perspectives to study translation practices. Hence, translation has been approached as a social practice and a cultural product more than a mere textualized activity. Inspired and motivated by the work of the French sociologist Pierre Bourdieu, translation scholars have paid sustained attention to the agency of translators. Inghilleri believes that translation scholars have become able to "analyze critically translators' role as social and cultural agents actively participating in the production and reproduction of textual and discursive practices" (2005:126). Bourdieu, an exponent of the "transgression of disciplinary boundaries", is well-known for his criticism of micro-level approaches to understand languages. He and his colleague aver that "one cannot fully understand language without placing linguistic practices within the full universe of various practices: eating and drinking habits, cultural consumption, taste in matters of arts, sports, dress, furniture, politics, etc." (Bourdieu and Wacquant 1992:149). To this end, a sociological analysis of any translation (both 
as process and product) attempts to understand the network of relationships between translation, and the translating agents who, in different ways, are involved in its production, dissemination, and consumption.

Drawing on the work of Bourdieu, this paper sets out to study Pickthall's The Meaning of the Glorious Koran: An Explanatory Translation as a socially situated activity that is both structured and is structuring within society. This paper shall proceed as follows: section two presents the objectives of the study. The rationale behind this paper will be explained in section 3. The theoretical framework which the study draws on will be introduced in section 4 . A review of the related literature will be presented in section 5. The research methodology will be detailed in section 6.A brief biography of Pickthall will be provided in section 7. The findings, and discussion will be examined in sections 8-11. Finally, section 12 will highlight some conclusions, and recommendations for future research.

\section{Objectives of the study}

The primary objective of this study is to propose an initial Bourdieusian model for studying and understanding the production of Pickthall's The Meaning of the Glorious Koran: An Explanatory Translation (1930). In this paper, the researchers aim to situate Pickthall's within the milieu of the field of English translations of the meaning of theHoly Quran. In addition, they aim to examine the paratextual material of this translation to decipher the strategies employed by Pickthall to defend and promote his position within this field, in terms of Bourdieu's concept of capital. This study is an attempt to answer the following questions:

1. What impact has Pickthall, as a socialized agent, exerted on the field of English translations of the meaning of theHolyQuran?

2. To what extent does the paratextual zone of Pickthall's The Meaning of the Glorious Koran: An Explanatory Translation (1930) express the strategies employed by Pickthall to accumulate capital at stake in the field?

\section{Rationale of the study}

Many studies have been conducted on English translations of the meaning of The Holy Quran. Most of these studies have been dedicated to discussing, assessing, comparing, and criticizing different translations (e.g., Rezvani and Nouraey2014; Siddiek 2017; Abdelaal 2019; and Jabak 2020, to name but a few). The focus of such studies is on the linguistics of Quran translations. However, the use of sociological approaches in studying translations of The Holy Quran has not been accorded adequate attention of scholars and researchers. Unlike the previous linguistic-oriented studies, this paper endeavors to study Pickthall's translation of The Quran through a sociological lens. The results of this paper reflect a fresh understanding of Pickthall's translation. Thus, this paper, which aims to investigate the application of Bourdieu's sociological theory on the study of the 
translation of such sensitive text, is justified.

\section{Theoretical framework}

Bourdieu's theory of cultural production seeks to analyze agents' practices and products by locating them in complex and overlapping networks of social agents. These agents are both individuals and institutions (e.g., authors, reviewers, translators, publishers, sponsors,) who contribute to the process of production, distribution, and consumption of a cultural product (Alkhawaja 2019:285). Bourdieu constructs his own sociology to fully account for the dialectical relationship between "the external and the internal, the conscious and the unconscious, and the bodily and the discursive" (Wacquant 1992:19). He revolutionizes the discipline of sociology by challenging the traditional philosophical theories. Two diametrically opposed schools of thought which considerably influenced Bourdieu's perspective were dominant in France in 1950s and 1960s. The first philosophy, represented by Sartre's Existentialism, considers human actions as "a kind of antecedent-less confrontation between the subject and the world" (Bourdieu, 1990:42). The second philosophy championed by LéviStrauss' Structuralism argues that the social world should be perceived as a complex structure of integrated components, while agents are secondary factors. To transcend this false dualism between the subject and the object, Bourdieu offers what he termed as 'thinking tools', i.e., field, capital, and doxa.

Bourdieu's concept of 'field' refers to the social contexts in which social activities and cultural products are produced, circulated, and consumed. He argues that one cannot fully understand interconnections between social agents or explain social practices without scrutinizing the social milieux within which such interactions and practices occur (Bourdieu 2005:148). Bourdieu differentiates three milieux : 1) the social space (or what is known as the society), 2) a given field of cultural production whose products are in question, and 3) the other fields which impact and interact with this field. Field, hence, might be defined as a hierarchically structured, quasi-autonomous space of objective relations between different positions occupied by social agents who create cultural production in accord with the unequal distribution of power, i.e., capital, whose possession guarantees access to profits at stake in the field (Bourdieu and Wacquant 1992:97).

Cultural producers tend to premise their products on an agreed-upon knowledge and opinions which are taken for granted among agents in a field. Such beliefs, according to Bourdieu, are termed as 'doxa'. They are the "preverbal taking-for-granted of the world" and are manifested in the "immediate adherence" between the object and subject (Bourdieu 1990:68). The fact that this relationship operates below the level of realization is what makes the world go without saying, and beyond questioning (Bourdieu 1977:166). However, once individuals start to be aware of them, these doxic practices begin to be questioned. Such questioning "brings the undiscussed into discussion, the unformulated into formulation" (Bourdieu 1977:168). Bourdieu states that questioning the doxic results in destroying the "immediate fit between the 
subjective structures and the objective structures" (1977:168). Understandably, questioning the doxa is a source of conflict between orthodoxy and heterodoxy discourses (Bourdieu 1977:164). Orthodoxy represents those dominant agents in the field who employ "conservative strategies", to consolidate their position and enjoy monopoly over a field's structure. Heterodoxy is usually adopted by newcomers, or already dominated agents in the field who deploy "subversion strategies", striving to challenge and question the existing doxa in order to occupy a more dominant position in the field (Bourdieu 1993:73). This fierce dispute between the two groups is not only on what is right or what is wrong, but also between "what is conventional and what is controversial" (Hanna 2016:46).

The structure and boundaries of a field, in effect, are not fixed and set once and for all. This is ascribable to the unequal distribution of capital (i.e., power and resources) among social agents in a field. Bourdieu borrows the concept of 'capital' from the Marxists to understand social practices and power relations among positions in fields. This term usually has economic connotation; however, he argues for reintroducing it to cover all forms of capital, "monetary and nonmonetary, as well as tangible and intangible forms" (1986:243). His main justification is that restricting the concept to its economic sense only would implicitly mean that other forms of exchange are disinterested and purposeless (1986:242). It is worth mentioning, however, that all other forms of capital should be viewed as "transubstantiated" forms of economic capital (Moore 2014:102).

The function of capital in any field is twofold: (1) it is "a force inscribed in objective or subjective structures", and (2) it is "the principle underlying the immanent regulations of the social world" (Bourdieu1986:241). To laymanise, capital is both the resource possessed by social agents, and the logic on which social spaces are (re)structured in the field. Capital might be defined as a term that covers "all the goods material and symbolic, without distinction, that present themselves as rare and worthy of being sought after in a particular social formation" (Bourdieu 1977:178). Based on the field in which it functions, capital might present itself in four forms: cultural capital, social capital, economic capital, and symbolic capital (Bourdieu 1986). Cultural capital is materialized in three forms: 1) the embodied form (knowledge, tastes, and experiences), 2) the objectified forms (books, dictionaries, and paintings), and 3) the institutionalized form (academic degrees, titles, and awards). Social capital is manifested in the resources acquired from a network of relationships. Economic capital is selfexplanatory; it indicates financial resources and assets. Symbolic capital is a generic type of capital possessed when other forms of capital are recognized legitimate by others. It is the resource available for social agents based on prestige and recognition.

\section{Literature Review}

Translating agents are in a perpetual struggle over accumulating capitals necessarily synonymous with dominant positions in a field. Such competition takes place within texts themselves, and beyond them in the paratextual zone. 
There has been an upsurge of interest in the study of translation from a sociological perspective. It is worth mentioning, however, and surprisingly, that most of these studies revolve around the field of literary translation. There is a lack of studies which attempt to adopt Bourdieu's sociology for the study of The Quran translation.

In light of Bourdieu's concept of capital, Song (2012) suggests an alternative interpretation of the social practice of retranslating classic texts. $\mathrm{He}$ presents how Sun Tzu's The Art of War, an ancient Chinese military treatise, is translated by two American translators: Grifith and Gary. By focusing on the role of the translators as social agents, Song scrutinizes how these translators invest in their cultural capital "to outmatch the competition" (2012:177). He explains the strategies each translator employs to qualify himself as 'the' translator of this time-honored classic text. A critical examination of the two translations shows that the translating agent's accumulation of cultural capital appears at two levels: textual and paratextual. Song concludes that the field of retranslating classic texts is a "lucrative field" in which translators struggle over authority. At face value, this struggle seems to be "about defending ideas and satisfying tastes." However, they aim to redistribute cultural capital, "which is regenerated and realized in the translational act ultimately "translated" into economic capital" (2012:188).

To bridge the false dichotomy between structure and agent, Ali (2018) argues for a "bidirectional understanding" of the paratextual elements of two Arabic translations of Gibran's The Earth Gods by Bashir (1932) and Okasha (1965). Bashir, Gibran's friend, produced the first English translation of The Earth Gods in which the size and the effect of his paratexts are insignificant. Ali imputes this to the fact that Bashir secured a full support from Gibran, and, thus, a high status as a translator in his society was achieved. Bashir's investment in his social capital is observable. By contrast, Okasha's paratextual material represents up to $55 \%$ of his translation. He seeks to produce not only a simple translation but also a "rich source of learning" (2018:95). Okasha questions the "second-order" position of translators and sets himself up as an author, instead of a mere translator. Ali infers that the paratextual zone might be viewed as sites of accumulating, attracting, and investing in one's capital in all its forms, which "contribute to a change in the economics of translation" (2018:98).

To the best knowledge of the researchers, up to date, there is only one study that introduces the "realm of sociology" into Quranic Studies. Bayri (2019) investigates the historical, cultural, and socio-political conditions under which Asad's habitus (i.e., dispositions) is structured, and in turn, structuring his translation of TheQuran. As a convert to Islam, Asad has two classes of habitus: the first one acquired among Europeans, and the second in an Islamic milieu. She infers that Asad's original habitus is observable in his Biblical lexical choices and the rendition of culture specificitems. She highlights the possibility 
of 'translatorial habituses' as strategic devices (re)structuring realities. Bayri concludes that capital might seem "subservient and serve as a vehicle" to espouse specific ideas and philosophies (2018:26). Although this study is properly conducted, Bayri focused mainly on the translator's habitus and did not pay due attention to the decisive role of capital and other concepts in (re)structuring the shape of the field in question at a given time. Thus, due to the lack of studies conducted on the sociology of English translations of the Holy Quran, this paper aspires to systematically examine Pickthall's The Meaning of the Glorious Koran through a Bourdieusianlens.

\section{Methodology}

Pickthall's translation of the meaning of The Holy Quran is selected for this study for many reasons. First and foremost, Muhammad Marmaduke Pickthall, as the first British Muslim to translate the meaning of the Holy Quran, is an influential figure who appeared during a critical period in the field of English translations of the meaning of the Holy Quran. Moreover, the paratextual zone of his translation provides an invaluable source of information of Pickthall's stances and milieu. Furthermore, the availability of substantial resources, e.g., biographies, articles, and documentaries, facilitates the exploration of his cultural and ideological underpinnings.

The analysis is carried out at two levels: the micro and the macro levels. Since translations do not exist in a vacuum, the researchers start the analysis by hypothesizing a field of activity which could be called 'the field of English translations of the meanings of the Holy Quran'. They contextualize the field within which these translations were produced through tracing the socio-cultural, and socio-political forces to delineate the field's structure and boundaries. After conducting an analysis at the macro level, the researchers carefully examine the paratextual zone of The Meaning of the Glorious Koran to reveal how Pickthall employed different strategies to secure himself and his translation a dominant position in the field.

\section{Pickthall, the process, and product}

The researchers believe that it is pivotal to provide a brief biography of Pickthall, as it had a formative influence on his translational decisions. It helps in scrutinizing the various factors that impacted the translator's choices and the milieu in which the translation was produced. Marmaduke William Pickthall (1865-1936) was a traveler, a novelist, a journalist, an editor, a school principal, a political and religious leader, a scholar, and an orientalist with remarkable linguistic skills. Pickthall is best known for being the first British Muslim to translate the meaning of The Holy Quran into English. His translation, which has never been out of print, is widely spread and read among anglophone Muslims (Clark 1994:281).

Pickthall was gifted with an exceptional ability to learn languages. He learned Greek, Latin, Welsh, Gaelic, French and Italian. His special talent for languages urged his teacher to suggest his name for a Foreign Office vacancy. 
Nonetheless, Pickthall, did not pass the exam to enter the Royal Engineers, nor had he become a member of the Levant Consular Service. Aspiring to learn enough Arabic to secure him a consular job at Palestine, he spent two years in Palestine and Syria. In Damascus, he devoted his time learning how to read Arabic properly and studying Arabic grammar. He was mesmerized by the lives of Middle Easterners to the extent that he lived in Khans and villages, learned their dialects, cherished their values and Islamic traditions. It is no wonder then that Pickthall thought of embracing Islam. Nonetheless, the Sheikh at the Umayyad Mosque dissuaded him from this step till he is older. Eventually, after twenty years, Pickthall opened a new chapter in his life. In 1917, in one of his lectures at the Muslim Literary Society, he openly declared his acceptance of Islam. In 1924, he moved to the state of Hyderabad, where he was the founding editor of a quarterly journal, Islamic Culture, which is considered as one of the foremost Islamic academic journals in the world.

The idea of translating the meaning of The Holy Quran had occupied Pickthall's mind for years. Kidwai (2017) suggests that the genesis of his project could be traced back into his article, "The Quran" that was published in The Islamic Review, and in which Pickthall expressed his concern that there were many people who "look on The Quran as an imposture whose only beauties are derived from plagiarism" (1919: 18). He attributed this to the fact that no translation he knew of can be praised because, according to him, most of the translators of The Quran have been "preoccupied by individual words which present difficulties, rather than by meaning as a whole" (1919:18). Subsequently, these translations seem 'prosy', 'discursive', and 'garrulous', whereas the original is "terse, majestic, and poetical" (Pickthall 1919:18). Hence, Pickthall declared that the fact that all existing translations are "misleading" was what urged him to think of producing a translation of his own.

Pickthall realized that he needed a stable base of income, and a patron to take on the task of publishing a groundbreaking English translation of the Holy Quran. When he secured the interest of Mir Osman Ali Khan, the Nizam of Hyderabad (i.e., the title of the monarch of Hyderabad State), Pickthall started his translation. From 1929 to 1931, and under the patronage of the Nizam, Pickthall was given a sabbatical for the sole purpose of fulfilling his ambition. Once the translation was completed, Pickthall decided to get the approval of AlAzhar. In 1929, he traveled to Egypt to get his translation thoroughly revised. However, Pickthall soon learnt that a group of powerful scholars thought that translating The Holy Quran is sinful and anyone who attempted to help Pickthall might lose his post. The controversy broke. Eventually, with the help of some powerful scholars, Pickthall won the battle. The senior scholars at Al-Azhar admitted their ignorance of the conditions of English-speaking Muslims. In 1930, Pickthall's translation, The Meaning of the Glorious Koran: An Explanatory Translation, published by Alfred A Knopf, and with a dedication to the Nizam of Hyderabad, came out in print. 


\section{The genesis of the field of English translations of the meaning of the Holy Quran}

It cannot be denied that there has always been a field of intellectual activity around the translations of Islamic sources, especially the translations of the Holy Quran, since the Middle Ages, Elgindey argues (2013:91). This field started to take shape when Orientalists translators have entered it. Activities in this field were informed by the beliefs of the Church. The main reasoning behind this is that those who had access and sufficient resources to finance Islamic studies were mainly churchmen. They sought to achieve "salvation of oneself and of wayward Middle Eastern Christians and Muslims" (Ansari 2011:75). Put differently, the functioning of this field was under the control of the Church which set the rules that defined the membership of this field. At that time, only those translators who proved willing to produce translations that go in line with the values of the Church were deemed true members in the field. To illustrate, Ross, who leaves no stone unturned to show his anti-Muslim combative attitude in his polemical translation, was the first to produce an English translation of The Quran. It has remained the source of information and served as the basis for potential English translations of The Quran. Ascribing The Holy Quran to the Prophet Mohammad, for example, is a trend replicated over and over throughout the history of the Western translation of The Quran. This is synonymous with what Bourdieu termed 'cultural reproduction'; it is the social process of transmitting cultural values from one generation to another through educational and religious institutions (1973:71).

Nonetheless, the Western intellectual field witnessed a drastic shift towards 'freethinking', by the end of the $17^{\text {th }}$ century. With the coming of the Enlightenment era, agents who had a different perspective of Islam had started to emerge in the field, claiming that 'pure scholarship', and 'lust for knowledge' were the mere drives behind their works. That is to say, the 'absolute' authority of the church started to weaken, whereas a secularized-informed perspective on history gained ground (Ansari 2011:76). Sale, to exemplify, deviated from the then Church's norms and marked a remarkable advance in the field by claiming to consult Islamic resources. By adopting a critical attitude towards Islam in his translation, he described the Prophet (PBUH), in an unprecedented manner, as the man who "gave his Arabs the best religion he could, as well as the best laws, preferable" (1734:ii). Moreover, new historical and literary criticism methods were adopted to study The Holy Quran. Almond opines that the Western discourse on Islam in the $19^{\text {th }}$ century concentrated, not on The Holy Quran, but rather on The Prophet himself, and that judgments of the former were made based on analysis of the latter's psychology (1989:77). In this respect, Rodwell, in his translation, rearranged the order of the Surahs chronologically to enable the 'attentive' reader to trace the development of the Prophet's character from a 'spiritual' figure to a 'warrior' and a 'founder of an empire' (1861:xi). By the late $19^{\text {th }}$ century, the Enlightenment has paved the way to political, religious, and scientific revolutions in British imperial history. Palmer, the first Arabist English 
translator of The Holy Quran, who advanced his knowledge of Arabic through his association with Arabs, had entered the field (Abdel Haleem 2017:261). He convincingly refuted the unsubstantiated claim that Islam is not Allah's religion. He emphasizes that "No religion, no sacred books of a religion, ever possessed entire originality" (1880:liii-liv). However, as much as these translations were considered as a revolt against the Church, they could not help but parroting the anti- Muslim attitude towards The Prophet as an 'imposter', and The Holy Quran as a'forgery'.

\section{Shifting the boundaries of the field: to translate or not totranslate}

The distorted image of Islam promoted in these English translations of The Holy Quran was about to be questioned, challenged, and replaced by the entrance of Muslim translators into the field. This in turn means that the structure of the field will be reconfigured, and consequently new positions will be offered. The beginning of the $20^{\text {th }}$ century marked a turning-point in the field. Nevertheless, one might wonder why Muslims were on the margin of the world and had no contributions in the field until that time. This might be imputed to the fact that the issue of (un) permissibility of translating The Holy Quran has caused controversy among Muslim scholars since the dawn of Islam. Abu Hanifa, to exemplify, was the first to beg the question of whether Quran translations might be recited in prayers for non-Arabs. He gave license to Persians to recite Persian translations of The Quran within daily prayers until they learn Arabic. Obviously, such a posture stands in stark contradiction to the other schools of thought, i.e., Maliki, Shafii and Hanbali, who believe that the inimitability of The Quran is inherent in both content and form.

The appearance of Muslim translators was accompanied with the appearance of new translating agents, i.e., religious, and academic institutions. Hence, the definition of the true membership of the field was not limited solely to translators but also involved those 'translating agents' who assumed the power of controlling the production of translations of The Holy Quran. Momentous socio-political events that are highly conducive to the development of Muslim scholars' position towards the permissibility of translating The Quran should be explored. After the dissolution of the Ottoman Empire, Al-Azhar emerged as the ultimate Islamic authority for deciding what is religiously credible. The rules governing the dynamism of this field were imposed in line with the beliefs of AlAzhar. It declared any translation activity of The Holy Quran to be sinful. Under the aegis of Al-Azhar, this field was enforced by the writings of the Syrian Egyptian scholar Rashīd Riḍa in his journal Al-Manar. It is safe to suggest that the pivotal role of Al-Azhar in deciding what Islamic resources to be translated defined the structure of the field at the beginning of the $20^{\text {th }}$ century. To demonstrate, those agents who attempt a translation of The Holy Quran are not considered, in the eyes of Al-Azhar, as true members of this field.

The boundaries of the field of English translations of The Holy Quran, however, are not set once and for all; instead, they are subject to changes over time. Boundaries of this field were redrawn in due to the appearance of new 
institutions who have radically different perspectives on Quran translating than the one adopted by Al-Azhar. The rise of the Ahmadiyya movement in the Indian subcontinent and its intense interest in translating Islamic texts into different languages have caused heightened tensions amongst agents in the field. This movement was declared by many mainstream Muslims to be out of the fold of Islam. Nonetheless, it seems that Ahmadis, are the most active proselytizers worldwide. The composition of several English translations of The Holy Quran have pushed the boundaries of thefield.

In 1925, the issue of (un) translatability of The Holy Quran was revitalized and exacerbated by the Ahmadi attempt to circulate Muhammad Ali's translation in the Arab world. The Egyptian Customs Office asked for the permission of AlAzhar to circulate the translation in Egypt. For Al-Azhar, as early indicated, the established doxa was not to translate The Holy Quran, not to mention translating it by an Ahmadi. Not surprisingly, then, Al-Azhar published a Fatwa in which they vehemently objected to its circulation. They decided to burn the translation in public in the courtyard of the Mosque of al-Azhar (Fremantle, 1938:408). Rashid Rida and the former Wakil of Al-Azhar Muhammad Shakir adopted the same position. They emphasized that it is a 'deviant' translation which aims to lead Muslims astray, and to destroy Islam from within (see Rida 1928; Shakir 1925). Although a field of cultural production is mainly autonomous, it is influenced by the field of power within which it is located (Bourdieu 1993:39). In our case, it can be observed how the field of English translations of the meanings of The Holy Quran in the Muslim world was dominated by the field of power, i.e., the religious field. Al-Azhar acted as 'the' gatekeeper of the field.

Apart from Ahmadiyya-driven translations of The Quran, Abul Fadl (1911/1912) and Hairat Dehlawi (1912) were the two earliest Muslim translators to produce English translations motivated principally from a "pious enthusiasm on their part to refute the allegations leveled by the Christian missionaries against Islam" (Sherif 2008:17). Although both AbulFadl and Dehlawi are given the credit to be the first Muslims to produce what might be termed 'faithful' English translations, they were not splendidly equipped to rise up to the challenge (Kidwai, 2017:232).

It might be reasonably observed that three groups of players, to use Bourdieu's terms, were active in this field prior to Pickthall: 1) Orientalist translators, 2) sectarian Muslim translators, and 3) unqualified Indian Muslim translators (Kidwai 2017:232). Against this background, Pickthall resolved to produce a translation of the meanings of The Holy Quran that reflects what he believed to be the "mainstream" of Islam.

\section{Challenging the doxic beliefs: Go-betweens vs. gatekeepers}

The concept of doxa facilitates the process of tracing the historical developments that have occurred in the field in question and it amply demonstrates the positions adopted by each translating agent at different stages in the field. Two binary poles are activated in the field once agents become aware of the doxa: 
orthodoxy and heterodoxy. Orthodoxy refers to the adherence to the 'accepted' rules set out by dominant agents in the field. Heterodoxy, by contrast, questions the current doxic values. Challenging these doxic assumptions means disrupting the relationships among positions in the field, and hence reconfiguring the structure of the field. Pickthall's The Meaning of the Glorious Koran (1930) clearly epitomizes the heterodoxic pole of the field. In 1929, Pickthall went to Egypt, seeking help in revising his English translation of the meanings of The Holy Quran before publishing it. When Pickthall landed in Egypt, he realized that the widely held belief among Ulamaa AL-Azhar is that all translating attempts of The Quran, however faithful, are deemed sinful. Pickthall, nonetheless, resolved to "break the silence of the doxa", to use Bourdieu's words.

Inspired by Bourdieu's schematization (1977:168), figure 1 is a diagramming of the two universes of doxa and opinion when Pickthall entered the field of English translations of The Holy Quran. As early indicated, the prereflexive beliefs were not to translate The Holy Quran. With the spread of Islam into the world, however, social agents of the field have become cognizant of the pressing need of translating The Holy Quran into foreign languages. Otherwise stated, what was, until that time, implausible, unsanctioned, and even sinful was about to be questioned. In the field of English translations of the meaning of The Holy Quran, the orthodox discourse is generated by Al-Azhar which implemented what Bourdieu refers to as 'conservation strategies' to consolidate its dominant position and maintain the structure of the field. On the other hand, the heterodox discourse is created by Pickthall and some powerful agents in the religious field such as, Shaykh Mustafa Al-Maraghai, Fuad Bey Selim al-Hijazi, and Muhammad Al-Ghamrawi. Justifying the imperative need to translate The Holy Quran, Pickthall deployed 'subversion strategies' to contest the existing doxic and replace it. He argued that there were non-Arab Muslims who were "as learned and devout, as capable of judgment, and as careful about the safety of Islam, as any to be found in Egypt" (1931:427).

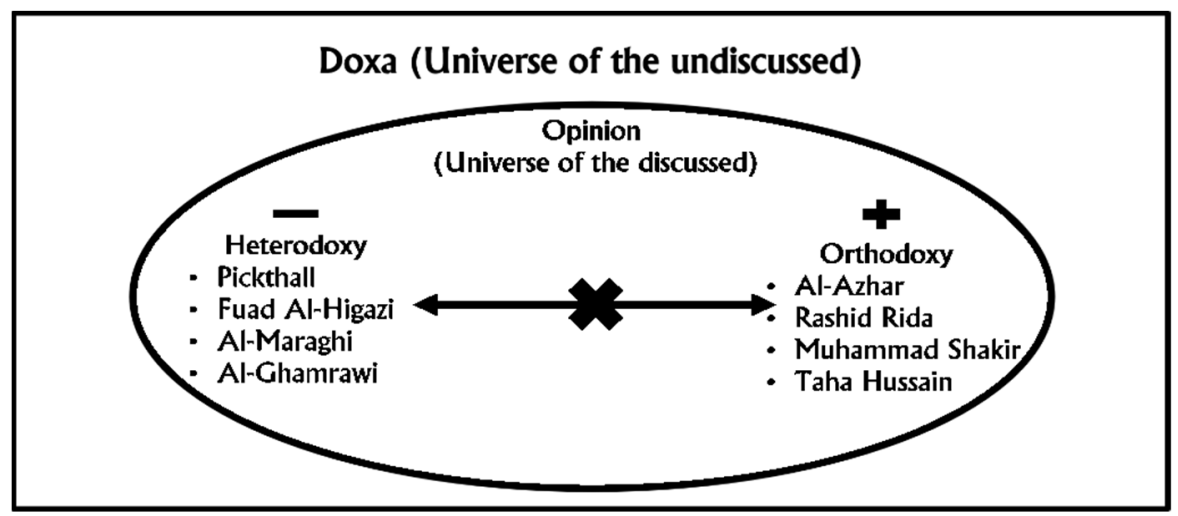

Figure 1. The universes of doxa and opinion when Pickthall entered the field of English translations of the meaning of The Holy Quran. 
Al-Maraghi, a former Rector of Al-Azhar, had been glad to "appoint a committee of the university" to revise the translation with Pickthall (Pickthall 1931:425). Regrettably, the plan was blown off course by the pressure of the King who vigorously opposed all translations of The Quran. As a result, the members of the committee could not afford the risk of losing their positions and sacrificing their symbolic capital in the field. Taha Huseyn, an Egyptian writer and one of the committee's members, urged Pickthall to meet the King personally in the hope that he might change his mind. However, Pickthall's response was that he did not come to Egypt to get a royal sanction for his work. $\mathrm{He}$ "had already got the sanction of His Exalted Highness"; nor had he come asking for "a fatwa from the Ulamaa of Egypt, [they] had perfectly competent Ulama in India" (Pickthall 1931:425). One can feel Pickthall's symbolic power which imposes his perceptions upon 'dominated' social agents.

Ultimately, Pickthall was introduced to Al-Ghamrawi, "a graduate of London University and a close student of the Quran", with whom he revised the translation for three months (1931:426). One day, Pickhall went out to a dinner party where he sat next to one of the most resourceful journalists. The next day, a piece of news that was headlined "A Translation of the Quran" appeared in AlAhram. Within two days, a piece of news having the same headline appeared in the same newspaper by Muhammad Shakir, in which he denounced the translation of The Holy Quran. Unsurprisingly, Shakir was "the leader of the hue-and-cry" against the circulation of Ali's translation in Egypt (Pickthall 1931:426). As a compromise, Pickthall was instructed to translate instead the commentary of Tabari. The response of Pickthall was swift. Flagging his cultural and symbolic capital in the field, he wrote a letter in which he meekly asked: "Is it lawful for an Englishman, who is a Muslim, who has studied the commentaries of the men of old and has some reputation as a man of letters with his countrymen, to try to expound the glorious Quran to his people in their own language at the present day?" (1931:426). This time, the reaction to Pickthall's letter from Shakir was an acknowledgment of Pickthall's translation that it is "not only lawful but meritorious" (Pickthall 1931:427).

Although the publication of Pickthall's translation is considered a challenge to the then prevalent doxa, it was at the same time an adherence to it. Deviating from the doxic is not unconditioned; it is rather played out with "the strategies of assimilation and dissimilation" (Bourdieu 1991:64). This means that any heterodoxic activities undertaken by newcomers are balanced by the minimum adherence to the regulations of the field. This minimum adherence, Hanna argues, is "the fee" that new agents should pay to preserve their membership in the field (Hanna 2016:139). Shrewdly, somehow Pickthall managed to affirm to the doxa, aspiring not to lose his symbolic capital. He decided to call his translation 'The Meaning of the Glorious Quran'. Accordingly, the Rector of Al-Azhar stated that "If he does that, then there can be no objection; we shall all be pleased with it" (Pickthall 1931:432). Moreover, he quite frankly stated, in his preface, his position towards translating The 
Quran: "The Koran cannot be translated. That is the belief of old-fashioned Sheykhsand the view of the present writer" (1930: vii; emphasis added). Citing the position of "old-fashioned Sheykhs" would further increase the volume of his capital.

It is safe to argue that Pickthall has made his mark in the field. The boundaries of the field have been extended, and new positions have been introduced. Questioning the doxic has opened the doors for new doxa to appear in the field. This might be epitomized in the changing of the minds of Ulamaa who were against translating The Quran. Following the publication of Pickthall's work, Al-Azhar decides to translate it word by word back into Arabic. Although the decision of Al-Azhar would be immaterial, Pickthall believes that such a step was "certainly a great advance beyond the method of condemning without trial pursued in the case of Maulvi Muhammad Ali's English version" (1931:432). Unfortunately, though the translation is the best of all the translations at that time, Al-Azhar based on literary considerations pronounced it to be "unfit to be authorized in Egypt" (Pickthall 1931:432). Nonetheless, it marked the end of "a long chapter in the history of the relations of Arabs and non-Arabs" (Pickthall 1931:432). Moreover, in 1936, only after six years of Pickthall's struggle, Shaykh Al-Maraghi sent the then Prime Minster a letter in which he proposed a project of translating The Holy Quran into several languages, asking for governmental support to produce a 'correct' translation of The Quran for Muslims. On April 16, 1936, the Cabinet of Egypt approved the execution of the translation project, based on an approval-fatwa issued by senior scholars of AlAzhar (Khafaji 1954:501-502). Indeed, Pickthall succeeded in destroying the 'self-evidence' of the social world, enjoying a high position in the field. But what were the resources Pickthall drew on to enter and restructure the field of English translations of the meanings of The Holy Quran?

\section{Capitalization on the paratextual zone of thetranslation}

Bourdieu opines that cultural producers are in a ceaseless struggle to accrue capital at stake in their field. The structure and limits of any field of cultural production are pursuant to the type and volume of capital available for agents in that field. Put differently, the position occupied by Pickthall in the field of English translations of The Holy Quran is determined by the type of capital accessible to him in the field in question. Whether calculatedly or inadvertently, the accumulation of and investment in capital is clearly played out in the paratextual zone of Pickthall's translation.

\subsection{Social capital}

Social capital refers to the potential resources available to the individual from durable social interactions. Bourdieu argues that the effect of social capital is pursuant on the size of the network of connection and on the volume of capital possessed by individual to whom the agent is connected (1986:249). Group membership yields both material and symbolic interests. In the case of Pickthall, one can feel the power of relationships in allowing him to enhance his social 
position in the field. Thanks to his "useful relationships" with the Nizam, the material profit of Pickthall's social capital is apparent in the Nizam's grant of a two-year sabbatical to complete his translation. Exchanging gifts, compliments, or any form of recognition is essential to foster links between agents, and the group of which they are members (Bourdieu1986:249).To return the favor, Pickthall dedicates the translation "to His Exalted Highness the Nizam" (1930). Pickthall is bestowing on himself and his translation a sense of power; potential readers will be assured that the translator and his translation are trustworthy with the backing of such a key figure in the field.

Other possible benefits accrued from Pickthall's social capital are manifested in his relationship with eminent figures of Al-Azhar. In his relatively short preface, Pickthall effectively underlines his relationship with Al-Maraghi, Fuad Bey, and Al-Gharmawi. He equipped himself with the necessary social capital to ensure that his 'masterpiece' is revised by knowing- English arbiters of Al-Azhar. He owes a lot to these scholars; if it were not for their support, Pickthall's translation might not have seen the light. As already indicated, the doxic was not to translate The Quran. However, this is where social capital comes into play. These Azhari scholars exercised the utmost of their power to surmount every difficulty encountered during the process of revising the translation. By drawing on the symbolic capital attached to these figures, Pickthall is likely to attract more attention to his translation, and consequently, raise his profile in the field.

\subsection{Cultural capital}

Pickthall's investment in his cultural capital is evident in the paratextual zone of his translation. Right from the beginning, Pickthall highlights his stance on the translatability of The Holy Quran, the Word of Allah. Pickthall opts for entitling his translation 'The Meaning of the Glorious Koran: An Explanatory Translation', highlighting several crucial elements. Titles are usually formed in a way that goes in line with the prevailing doxic beliefs of the receiving audience. Inserting terms such as 'meaning', and 'explanatory' indicates that the work is a mere 'interpretation attempt' of The Quran; it was never meant to take the place of The Quran. His title choice exemplifies an investment in his embodied cultural capital, which might be viewed as a potential deployed by Pickthall to comply with the requirements of Al-Azhar to safeguard his position in the field.

Although Pickthall embraced Islam and changed his name from Marmaduke into Muhammad in 1917, his first name 'Marmaduke' is recorded on the title page. Genette argues that the name of the author, and in our case the name of the translator, is not a mere "straightforward statement of identity' but rather a way to put "an identity, or rather a "personality," as the media calls it, at the service of the book" (1997:40). Pickthall builds up a good reputation as a man of letters among his people. Pickthall decides to foreground the fact that the translation was carried out by a native speaker of English rather than by a Muslim. It might be assumed that adopting the non-Muslim name might not be an innocent gesture; it has a crucial role in the process of marketing the 
translation. One could suggest that this would attract English readers' attention to the translation. It might be safely suggested that Picthall's investment in his embodied cultural capital has contributed to maximizing his symbolic and economic capital.

To attain more legitimacy, Pickthall is eager to highlight the distinctive value of his translation. He states that the work "has been scrutinized word by word and thoroughly revised in Egypt ... and when difficulties were encountered the translator has recourse to perhaps the greatest living authority on the subject" (1930: vii, emphasis is added). Obviously, Pickthall is drawing on his institutionalized cultural capital, "a certificate of cultural competence" (Bourdieu 1986:246). This would perhaps maximize Pickthall's symbolic and economic capital in the field. Stated another way, by being known as 'the' first translator whose translation is revised by Al-Azhar, Pickthall is more likely to be placed in a dominant position in the field, and subsequently, his symbolic capital shall be increased.

Subverting the products of the past "consecrated" producers is necessary to achieve one's difference in the field (Bourdieu 1993:106). Such difference is an integral part of one's cultural capital and is represented in the strategies one employs to introduce new positions into the field. Taking this into account, Pickthall, being a newcomer, strives to employ different forms of distinction to lend validity to his cultural product. To illustrate, Pickthall indirectly criticized previous English translation of The Holy Quran. In his preface, he claimed that "no Holy Scripture can be fairly presented by one who disbelieves in its inspiration and its message" (1930:vii). This in turn means that, without the need to directly refer to the previous translations of The Quran carried out by 'disbelievers', he devalued their translations as 'fair presentations' of The Quran. Asserting further the salience of his 'enterprise', Pickthall labels other translations of The Quran as including "commentation offensive to Muslims, and almost all employ a style of language which Muslims at once recognize as unworthy" (1930:vii). As a solution, Pickthall offers readers "the first English translation of the Koran by an Englishman who is a Muslim" (1930:vii). Nonetheless, Pickthall, in all humbleness, acknowledges that his translation is merely an "attempt" to present the meanings of The Holy Quran in English. Such an attitude might be explained as a step to ward off any criticism against his translation. From a different point of view, one might also consider that Pickthall is endeavoring to be fully cognate with the Muslim orthodoxy. Either way, this is likely to improve Pickthall's profile.

Pickthall also aspires to correct some misconceptions about The Holy Quran in the mind of the Westerns. To illustrate, although he admitted that the arrangement of the Surahs is not easily comprehensible, he defended the divinely order of the Surahs. He states that: "the arrangement is not haphazard, as some have hastily supposed." (1930:19; emphasis is added). Rodwell is the first to provide an English translation of The Quran with a critical reordering of the Surahs chronologically, followed by the Muslim translator Abu'lFadl. 
Apparently, Pickthall implicitly expresses his criticism against these translators. By marking the deficiencies of his previous "rivals", Pickthall places lasting value on his cultural capital and protects his reputation within the field. Pickthall manages to reduce the competition and establish the "monopoly" over the field in question for a long period oftime.

\section{A look into the whole picture: Conversion of capital}

Bourdieu emphasizes on the convertibility of one form of capital into others. He believes that "the convertibility of the different types of capital is the basis of the strategies aimed at ensuring the reproduction of capital" (1986:253). Pickthall's cultural assets and social connections have endowed Pickthall with the symbolic capital, which places him in a leading position amid other translating agents in the field. Pickthall knew how to play his cards right. Who could deny the symbolic capital attached to Pickthall after the publication of his translation? The virtually unanimous opinion is that Pickthall has succeeded in being the first to produce a 'first- rate' translation of The Quran, moving his readers to 'tears and ecstasy' (Kidwai 2017:231). This is manifested in the global outreach of Pickthall's magnum opus. Up to now, more than 160 editions have been issued and widely spread (Kidwai 2007:75-76).

Enhancing the value of cultural products is not only determined by the 'actual' producers, i.e., translators. It is also dependent on the practices of other cultural producers, such as reviewers, critics, etc., who either praise or disparage these cultural products. Indeed, such social agents intervene "in the production of the work, its meaning and value" (Bourdieu 1993:110). Pickthall's amassment of symbolic capital seems to be significantly increased because of field-specialists' reviews. Mohammad Ali of Lahore commended the work: "at last, thank God, we have a real translation", to which Fuad Bey Salim added: "it is an inspired translation" (qtd. in Fremantle 1938:421). Moreover, Arberry, one of the most prominent non-Muslim translators of The Quran into English, exalted: it is "an important milestone in the long course of Koranic interpretation" (1996:21). Last but not least, Kidwai, a prominent scholar with dozens of publications on English translations of The Quran, praised the work, saying: it "has been remarkably successful [...] in inspiring scores of later Muslim scholars to embark upon their own Quran translations" (2017:231). Unquestionably, such reviews play a vital role in asserting Pickthall's position in the field.

\section{Conclusion}

This study reveals that translation is an activity that is tightly woven into the social fabric of society, produced by agents who are the products and the (re)producers of their societies. The outstanding contribution of Bourdieu's sociological model to Translation Studies lies in providing conceptual and methodological tools indispensable to explore the social dimension of translation practices. Since translation activities, particularly Quran translations, are not 
produced in vacuum, it is inescapable that they should be studied in relation to the translating agents who produce them, and within the milieux which decisively determine their production, circulation, and consumption.

Drawing on Bourdieu's sociology, the researchers propose a fresh understanding of Quran translations, away from the traditional linguistic perspective. This article explored Pickthall's The Meaning of the Glorious Koran a social activity, situated in a social space, and carried out by translating agents who are in a ceaseless struggle over accumulating capital at stake in the field. A paratextual analysis of the translation indicates that the translator employed various strategies to establish the "monopoly" over the field for a long period of time. The findings of this study reveal that the field of English translations of the meaning of The Holy Quran is a field of battle over distinction.

Although this study has hopefully produced fruitful findings, there are several areas that are still subject of inquiry. Since this study is limited to analyze the pretexts of the work, exploring covert and overt claims of distinction at the textual micro-level, and analyzing the way in which translating agents opt for specific lexical items to legitimize their translation is highly recommended. Addressing such issues should significantly contribute to the sociological turn in Quranic studies.

Dana Muwafi

University of Sharjah, UAE

ORCID Number: 0000-0002-1196-9250

Email: u18104500@sharjah.ac.ae

Shehdeh Fareh

University of Sharjah, UAE

ORCID Number: 0000-0002-1196-9250

Email: shfareh@sharjah.ac.ae 


\section{References}

Abdel Haleem, Muhammad. (2017). Exploring the Qur'an: Context and Impact. London: I.B.Tauris.

Abdelaal, Noureldin Mohamed. (2019). 'Translating denotative meaning in the Holy Quran: Problems and solutions.' Pertanika Journal of Social Sciences \& Humanities, 27(1): 13-33.

Abul Fadl, Mirza. (1911). The Qur'an: Arabic Text and English Translation Arranged Chronologically with an Abstract. Allahabad: G. A. Asghar \& co.

Ali, Hisham. (2018). 'Bourdieu and Genette in paratext: How sociology counts in linguistic reasoning'. International Journal of Society, Culture \& Language, 6 (2): 90-101.

Alkhawaja, Linda. (2019). 'Network and cooperation in the field of cultural production: Naguib Mahfouz in translation'. International Journal of Arabic-English Studies, 19(2), 281-292.

Almond, Philip. Heretic and Hero: Muhammad and the Victorians. Wiesbaden: Otto Harrassowitz Verlag, 1989.

Ansari, Humayun. (2011). 'The Muslim world in British historical imaginations: 'Re-thinking “orientalism”?'. British Journal of Middle Eastern Studies, 38 (1): 73-93.

Arberry, Arthur. (1996). The Koran Interpreted: A Translation. New York: Simon and Schuster.

Bayri, Furzana. (2019). 'Li-Qawminyatafakkarun (Q. 30:21): Muhammad Asad's Qur'anic translatorialhabitus'. Journal of Quranic Studies, 21 (2): 138.

Bourdieu, Pierre and LoïcWacquant. (1992). An Invitation to Reflexive Sociology. Chicago: University of Chicago Press.

Bourdieu, Pierre. (1973). 'Cultural reproduction and social reproduction'. In: Richard Brown (ed.), Knowledge, Education, and Culture Change, 257270. London: Tavistock Publications.

Bourdieu, Pierre. (1977). Outline of a Theory Practice (Richard Nice, Trans.). Cambridge: Cambridge University Press.

Bourdieu, Pierre. (1986). 'The forms of capital'. In: John Richardson (ed.), Handbook of Theory and Research for the Sociology of Education, 241-258. New York: Greenwood Press.

Bourdieu, Pierre. (1990). The Logic of Practice (Richard Nice, Trans.). Stanford: Stanford University Press.

Bourdieu, Pierre. (1991). Language and Symbolic Power. Cambridge: Harvard University.

Bourdieu, Pierre. (1993). The Field of Cultural Production: Essays on Art and Literature. New York: Columbia University Press.

Bourdieu, Pierre.(2005). The Social Structure of the Economy (Chris Turner, 
Trans.). Cambridge: Polity Press.

Clark, Peter. (1986). Marmaduke Pickthall: British Muslim. London: Quartet Books.

Clark, Peter. (1994). 'A Man of two cities: Pickthall, Damascus, Hyderabad'. Asian Affairs. 25 (3): 270-280.

Elgindy, Ahmad. (2013). Translation and the construction of the religious other: A sociological approach to English translations of Islamic political texts. Published PhD Thesis, University of Salford, Salford, United Kingdom.

Fremantle, Anne. (1938). Loyal Enemy. London: Hutchinson \& Company.

Genette, Gérard. (1997). Paratexts: Thresholds of Interpretation (Lewin, Trans.). Cambridge: Cambridge University Press.

Hanna, Sameh. (2016). Bourdieu in Translation Studies: The Socio-cultural Dynamics of Shakespeare Translation in Egypt. New York: Routledge.

Inghilleri, Moira. (2005). 'The sociology of Bourdieu and the construction of the 'object' in translation and interpreting Studies'. The Translator, 11 (2): 125145.

Jabak, Omar Osman. (2020). 'Application of Eugene Nida's theory of translation to the English translation of surah Ash-Shams'. Transcultural: A Journal of Translation and Cultural Studies, 12.2: 3-18.

Khafaji, Mohammad. (1954). Al-Azhar Fi Alf Aam. Cairo: Al-Matbaa AlMunieriaaBil.

Kidwai, Abdur Raheem. (2007). Biography of the Translations of the Meaning of the Glorious Koran into English 1649-2002. Medina: King Fahad Quran Printing Complex.

Kidwai, Abdur Raheem. (2017). 'Muhammad Marmaduke Pickthall's English translation of the Quran (1930): An assessment'. In Geoffrey Nash (ed.), Marmaduke Pickthall: Islam and the Modern World, 231-248. Netherlands: Brill.

Moore, Robert. (2014). 'Capital'. In Michael Grenfell (ed.), Pierre Bourdieu: Key Concepts, 98-112. United Kingdom: Routledge.

Palmer, E. H. (1880). The Qur'an: Translated by E. H. Palmer. Oxford: Clarendon Press.

Pickthall, Marmaduke. (1930). The Meaning of the Glorious Koran: An Explanatory Translation. New York: Alfred. A. Knopf.

Pickthall, Marmaduke. (1919). 'The Quran'. The Islamic Review and Muslim India. 7, 9-18.

Pickthall, Marmaduke. (1931). 'Arabs and non-Arabs and the question of translating the Koran'. Islamic Culture. 5,422-433.

Rezvani, Reza, and Peyman Nouraey. (2014). 'A comparative study of shifts in English translations of the Quran: A case study on "Yusuf" chapter"'. Khazar Journal of Humanities and Social Sciences, 70-87.

Rida, Mohammad. (1928). 'Tarjamat Muhammad Ali Al-Handi li Al-Quran'. AlManar Journal. 29,268-269.

Rodwell, John. (1861). The Koran: Translated from the Arabic, the Suras Arranged in Chronological Order with Notes and Index. London: Williams 
and Norgate.

Ross, Alexander. (1649). THE ALCORAN OF MAHOMET Translated out of Arabique into French; BY THE Sieur Du Ryer, Lord of Malezair, and Resident for the King of France, at ALEXANDRIA. And Newly Englished, for the Satisfaction of all that Desire to Look into the Turkish Vanities. London: U.K. Retrieved July 19, 2020 from the World Wide Web: https://quod.lib.umich.edu/cgi/t/text/text$\mathrm{idx}$ ?c=eebo;idno=B25542.0001.001

Sale, George. (1734). The Koran: Commonly Called the Alcoran of Mohammed; translated into English immediately from the Original Arabic with Explanatory NOTES, taken from the Most Approved COMMENTATORS to which is Prefixed a Preliminary Discourse. London.

Shakir, Mohammad. (1925). Al-Qaul Al-Fasl fi Tarjamat Al-Quran Al-Karim ila Al-Lughat Al-Aajamiyah. Cairo: Matbaat Al-Nahdah.

Sherif, M. A. (2008). The Abdullah Yusuf Ali Memorial Lecture. New York: Other Press.

Siddiek, Ahmed Gumaa. (2017). 'Linguistic precautions that to be considered when translating the Holy Quran'. Advances in Language and Literary Studies. 8(2): 103-111.

Song, Zhongwei. (2012). 'The Art of War in retranslating Sun Tzu: Using cultural capital to outmatch the competition'. Translation and Interpreting Studies.7(2): 176-209.

Wacquant, Loïc. (1992). 'Towards a social praxeology: The structure and logic of Bourdieu's sociology'. In Pierre Bourdieu and Wacquant Loïc (ed.), An Invitation to Reflexive Sociology, 1-60. Chicago: University of Chicago Press 